\title{
Pengaruh Kompetensi Dan Kepemimpinan Transformasional Terhadap Produktivitas Kerja Karyawan PT Jasa Swadaya Utama
}

\author{
Agus Setiarlan, Ahmadun, Nurminingsih, Asim \\ Program Studi Administrasi Bisnis Universitas Respati Indonesia \\ aguserlan88@gmail.com,
}

\begin{abstract}
ABSTRAK
Penelitian ini bertujuan untuk meneliti Pengaruh Kompetensi dan Kepemimpinan Transformasioanal terhadap Produktivitas Kerja Karyawan pada Perusahaan PT Jasa Swadaya Utama. Penelitian ini merupakan jenis penelitian deskriptif kuantitatif. Populasi penelitian sebanyak 98 orang. teknik analisis data yang digunakan analisis Statistik deskriptif sedangkan Metode Analisis yang digunakan dalam penelitian ini adalah PLS (Partial Least Square) menggunakan SmartPLS versi 3.0.m3. Hasil penelitian menunjukkan bahwa Kompetensi berpengaruh positif dan signifikan terhadap Produktivitas Kerja dan Kompetensi berpengaruh positif dan signifikan terhadap kepemimpinan transformasional. Sedangkan Kepemimpinan Transpormasional berpengaruh positif dan signifikan terhadap produktivitas kerja. pengujian secara simultan hasil analisis data menunjukkan bahwa Kompetensi dan Kepemimpinan Transpormasional berpengaruh positif dan signifikan terhadap produktivitas kerja sedangkan sisanya dipengaruhi faktor lain.
\end{abstract}

\section{Kata Kunci : Produktivitas Kerja, Kompetensi dan Kepemimpinan Transformasional}

\begin{abstract}
This study aims to examine the effect of competence and transformational leadership on employee work productivity at PT Jasa Swadaya Utama. This research is a quantitative descriptive research. The study population was 98 people. The data analysis technique used is descriptive statistical analysis, while the method of analysis used in this study was PLS (Partial Least Square) using SmartPLS version 3.0.m3. The results showed that competence has a positive and significant effect on work productivity and competence has a positive and significant effect on transformational leadership. Meanwhile, transformational leadership has a positive and significant effect on work productivity. Simultaneous testing of the results of data analysis shows that competence and transformational leadership have a positive and significant effect on work productivity while the rest is influenced by other factors.
\end{abstract}

\section{Keyword : Work Productivity, Competence and Transformational Leadership}




\section{PENDAHULUAN}

Produktivitas kerja karyawan sangat diharapkan pada suatu organisasi atau perusahaan, agar dapat mencapai target kerja serta untuk menjaga perusahaan agar tetap berjalan dengan baik. Beberapa faktor yang mempengaruhi produktivitas kerja seseorang, diantaranya adalah pengetahuan, keterampilan, kemampuan dan sikap. Kompetensi juga menunjukkan karakteristik pengetahuan dan keterampilan yang dimiliki atau dibutuhkan oleh setiap individu yang memampukan mereka untuk melakukan tugas dan tanggung jawab mereka secara efektif dan meningkatkan standar kualitas profesional dalam pekerjaan mereka. Kompetensi yang dimiliki oleh setiap karyawan sangat dibutuhkan agar dapat membantu pimpinan dalam menciptakan nilai dan memberikan kontribusi terhadap strategi dalam suatu perusahaan. Kompetensi setiap karyawan berbeda - beda, jadi dalam penempatan tugaspun haruslah sesuai dengan kemampuan karyawannya. Jika kompetensi tidak sesuai dengan penempatan tugasnya, maka produktivitas kerja yang diharapkan perusahaan tidak akan efektif dan efisien.

\section{Pembahasan}

mengenai produktivitas kerja juga dikaitkan dengan kepemimpinan transformasional yang digunakan oleh pimpinan perusahaan. Untuk mendapatkan hasil kerja karyawan yang baik pimpinan perusahaan melakukan kerja sama dan monitoring ke bawah, sehingga dapat mengetahui kelebihan dan kekurangan yang ada pada karyawannya. Menurut Keith Davis dalam (Nurarif \& Kusuma, 2013) yang menyatakan sifat umum yang mempengaruhi kesuksesan kepemimpinan transformasional dalam organisasi yaitu : intelegensia, kematangan sosial, motivasi diri, hubungan pribadi. Kepemimpinan transformasional merupakan kemampuan untuk mempengaruhi orang lain untuk mencapai tujuan dari suatu organisasi atau perusahaan. Sosok seorang pemimpin sangat dibutuhkan dalam rangka mendorong karyawannya agar mampu meningkatkan kualitas perusahaan terutama melalui motivasi dan peningkatan kinerja karyawan.

Sumber daya manusia merupakan faktor penting yang menentukan kelangsungan hidup suatu perusahaan, maka karyawan menjadi aset yang lebih penting dibanding faktor produksi lainnya. Demikian juga yang terjadi di PT Jasa Swadaya Utama. Sumber daya manusia merupakan faktor yang sangat penting mengingat $\mathrm{PT}$ Jasa Swadaya Utama adalah perusahaan yang bergerak dalam bidang jasa penyediaan tenaga Security, Office Service, Messenger, dan Driver. Sebagai perusahaan yang berfokus pada pengembangan SDM, PT Jasa Swadaya Utama menyelenggarakan kegiatankegiatan yang bergerak di bidang pengamanan, Office Service, Messenger, dan Driver. ditemukan 
bahwa latar belakang pendidikan karyawan kantor pusat masih kurang memadai, bahkan di level pimpinan. Karyawan yang pendidikan S2 hanya satu orang, sehingga kurang mengutamakan pengetahuan dan kemampuan. Akibatnya penempatan pegawai tidak sesuai dengan kemampuan yang dimilikinya dan menyelesaikan tugas sering tidak sesuai dengan waktu yang sudah ditetapkan. t.

\section{METODE}

jenis $\begin{array}{cr}\text { Penelitian ini menggunakan } \\ \text { penelitian }\end{array}$

kuantitatif, Dalam penelitian ini pengambilan sampel dengan menggunakan teknik total sampling populasi yang digunakan bersifat heterogen karena karyawan kantor pusat PT Jasa Swadaya Utama terdiri dari beberapa divisi dengan status karyawan tetap sebanyak 40 orang dan karyawan kontrak sebanyak 58 orang, sehingga polulasi dijadikan sampel penelitian semuanya. Metode analisis data menggunakan analiasi Structural Equation Modeling- Partial Least Square (SEM-PLS) software Smart PLS versi 3.0.

\section{Model Analisis Persamaan Struktural}

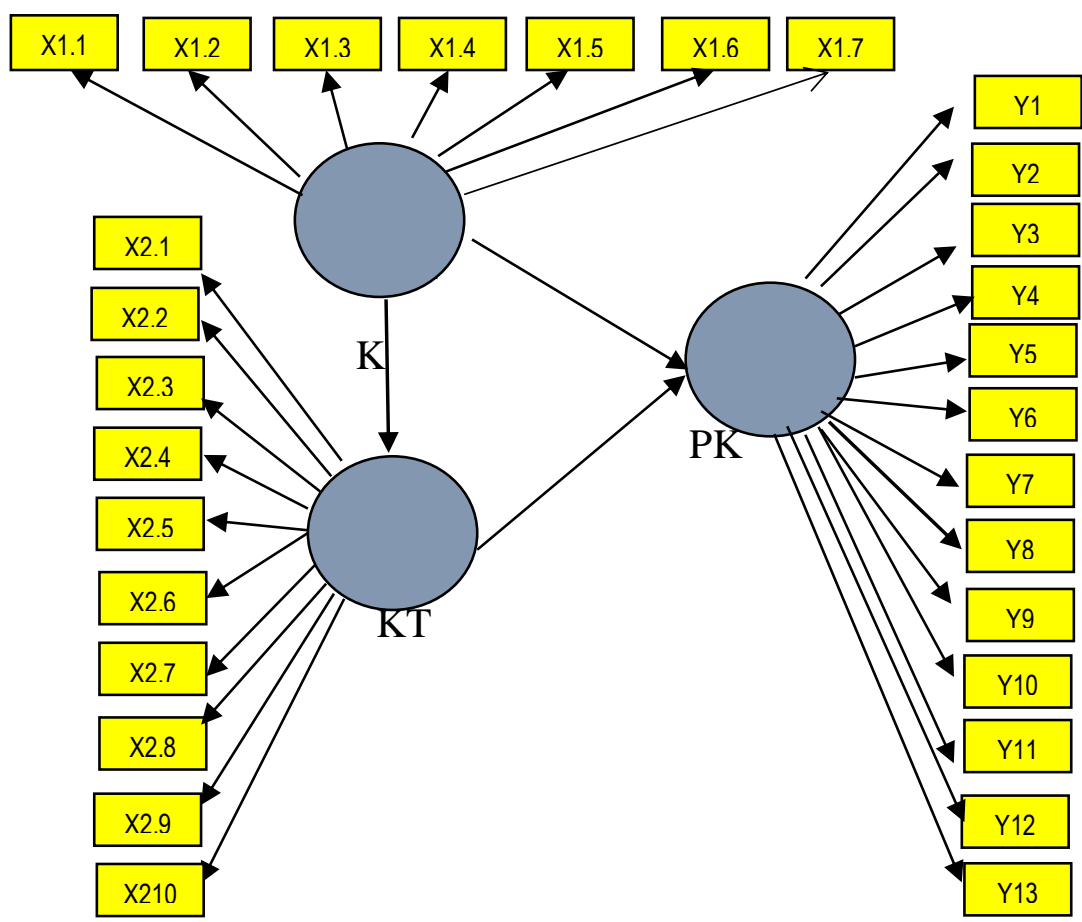

Keterangan :

$\mathrm{K}=$ Kompetensi (X1)

$\mathrm{KT}=$ Kepemimpinan Transformasional (X2)

$\mathrm{PK}=$ Produktivitas $\operatorname{Kerja}(\mathrm{Y})$ 


\section{HASIL}

\section{Karakteristik Responden berdasarkan Jenis Kelamin}

\begin{tabular}{|cl|r|r|r|r|}
\hline & Frequency & $\begin{array}{c}\text { Percen } \\
\mathrm{t}\end{array}$ & $\begin{array}{c}\text { Valid } \\
\text { Percent }\end{array}$ & $\begin{array}{c}\text { Cumulative } \\
\text { Percent }\end{array}$ \\
\hline \multirow{2}{*}{ Valid } & Laki-laki & 80 & 81.6 & 81.6 & 81.6 \\
Perempuan & 18 & 18.4 & 18.4 & 100.0 \\
Total & 98 & 100.0 & 100.0 & \\
\hline
\end{tabular}

Sumber : Data diolah SPSS 20 tahun 2020

Berdasarkan tabel di atas menunjukkan bahwa karyawan kantor pusat PT. Jasa Swadaya Utama dengan jenis kelamin lakilaki sebanyak 80 orang $(81,6 \%)$ dan jenis kelamin perempuan sebanyak 18 orang $(18,4 \%)$. Hal ini menunjukkan bahwa mayoritas yang menjadi karyawan kantor pusat PT. Jasa Swadaya Utama berjenis kelamin laki-laki $(81,6 \%)$, karena karyawan dengan jenis kelamin laki-laki memiliki daya tahan fisik yang lebih kuat.

\section{Karakteristik berdasarkan Usia}

Deskripsi

karakteristik karyawan kantor pusat PT. Jasa Swadaya Utama berdasarkan usia disajikan pada tabel berikut ini:

\begin{tabular}{|c|c|c|c|c|c|}
\hline & & $\begin{array}{c}\text { Frequenc } \\
y\end{array}$ & Percent & $\begin{array}{c}\text { Valid } \\
\text { Percent }\end{array}$ & $\begin{array}{c}\text { Cumulative } \\
\text { Percent }\end{array}$ \\
\hline & 20-30 tahun & 29 & 29.6 & 29.6 & 29.6 \\
\hline & $31-40$ tahun & 41 & 41.8 & 41.8 & 71.4 \\
\hline Valid & $41-50$ tahun & 21 & 21.4 & 21.4 & 92.9 \\
\hline & $>50$ tahun & 7 & 7.1 & 7.1 & 100.0 \\
\hline & Total & 98 & 100.0 & 100.0 & \\
\hline
\end{tabular}

Sumber : Data diolah SPSS 20 tahun 2020

Berdasarkan tabel di atas menunjukkan bahwa karyawan kantor pusat PT. Jasa Swadaya Utama berusia 20 - 30 tahun sebanyak 29 orang $(29,6 \%)$, berusia 31 - 40 tahun sebanyak 41 orang $(41,8 \%)$, berusia $41-50$ tahun sebanyak 21 orang $(21,4 \%)$, dan berusia di atas 50 tahun sebanyak 7 orang $(7,1 \%)$. Hal ini menunjukkan bahwa mayoritas yang menjadi karyawan PT. Jaya Swadaya Utama berusia produktif yakni usia 20 - 30 tahun $(29,6 \%)$ dan usia 31 - 40 tahun $(41,8 \%)$. Berdasarkan hasil survei menyatakan bahwa mayoritas usia pekerja di kantor pusat PT Jasa 
Swadaya Utama termasuk karyawan yang sangat produktif. Sehingga akan mempunyai korelasi yang positif terhadap produktivitas kerja karyawan.

\section{Karakteristik berdasarkan Terakhir}

Responden Pendidikan

Deskripsi

karakteristik karyawan kantor pusat PT. Jasa Swadaya Utama berdasarkan pendidikan terakhir disajikan pada tabel berikut ini:

\begin{tabular}{|rl|r|r|r|r|}
\hline & & Frequency & Percent & $\begin{array}{c}\text { Valid } \\
\text { Percent }\end{array}$ & $\begin{array}{c}\text { Cumulative } \\
\text { Percent }\end{array}$ \\
\hline \multirow{4}{*}{ Valid } & SLTA & 58 & 59.2 & 59.2 & 59.2 \\
D1- & 1 & 1.0 & 1.0 & 60.2 \\
D3 & 38 & 38.8 & 38.8 & 99.0 \\
& S1 & 1 & 1.0 & 1.0 & 100.0 \\
S2 & 98 & 100.0 & 100.0 & \\
\hline
\end{tabular}

Sumber : Data diolah SPSS 20 tahun 2020

Berdasarkan Tabel di atas menunjukkan bahwa karyawan kantor pusat PT. Jasa Swadaya Utama berpendidikan SLTA sebanyak 58 orang $(59,2 \%)$, berpendidikan DI/DIII sebanyak 1 orang (1\%). Sedangkan Karyawan dengan pendidikan S1 sebanyak 38 orang $(38,8 \%)$, serta karyawan dengan pendidikan S2 sebanyak 1 orang $(1 \%)$.
Karakteristik Berdasarkan Masa Kerja

Deskripsi

karakteristik karyawan kantor pusat PT. Jasa Swadaya Utama berdasarkan masa kerja disajikan pada tabel berikut ini:

\begin{tabular}{|r|r|r|r|r|}
\hline & Frequency & Percent & $\begin{array}{c}\text { Valid } \\
\text { Percent }\end{array}$ & $\begin{array}{c}\text { Cumulative } \\
\text { Percent }\end{array}$ \\
\hline & 15 & 15.3 & 15.3 & 15.3 \\
tahun & 19 & 19.4 & 19.4 & 34.7 \\
$\begin{array}{l}3-4 \\
\text { tahun }\end{array}$ & 17 & 17.3 & 17.3 & 52.0 \\
Valid & $5-6$ & & & \\
tahun & & & \\
$>6$ & 47 & 48.0 & 48.0 & 100.0 \\
tahun & 98 & 100.0 & 100.0 & \\
\hline Total & &
\end{tabular}

Sumber : Data diolah SPSS 20 tahun 2020 
Berdasarkan Tabel di atas menunjukkan bahwa karyawan kantor pusat di PT. Jasa Swadaya Utama dengan masa kerja di bawah 3 tahun sebanyak 15 orang $(15,3 \%)$, masa kerja 3-4 tahun sebanyak 19 orang $(19,4 \%)$, masa kerja 5-6 tahun sebanyak 17 orang $(17,3 \%)$, dan masa kerja di atas 6 tahun sebanyak 47 orang (48\%).

\section{Karakteristik Berdasarkan Gaji}

Deskripsi karakteristik karyawan kantor pusat PT. Jasa Swadaya Utama berdasarkan gaji disajikan pada tabel berikut ini:

\begin{tabular}{|ll|r|r|r|r|}
\hline & $\begin{array}{c}\text { Frequenc } \\
y\end{array}$ & Percent & $\begin{array}{c}\text { Valid } \\
\text { Percent }\end{array}$ & $\begin{array}{c}\text { Cumulative } \\
\text { Percent }\end{array}$ \\
\hline \multirow{4}{*}{ Valid $\quad$ < juta } & 54 & 55.1 & 55.1 & 55.1 \\
& $5-10$ juta & 36 & 36.7 & 36.7 & 91.8 \\
& $11-15$ & 6 & 6.1 & 6.1 & 98.0 \\
& juta & 2 & 2.0 & 2.0 & 100.0 \\
& $>15$ juta & 98 & 100.0 & 100.0 & \\
\hline
\end{tabular}

Sumber : Data diolah SPSS 20 tahun 2020

Berdasarkan Tabel di atas menunjukkan bahwa karyawan kantor pusat PT. Jasa Swadaya Utama menerima gaji di bawah 5 juta rupiah perbulan sebanyak 54 orang $(55,1 \%)$, menerima gaji 5 juta rupiah sampai 10 juta rupiah perbulan sebanyak 36 orang (36.7\%), menerima gaji 11 juta rupiah sampai 15 juta rupiah perbulan sebanyak 6 orang $(6,1 \%)$, dan menerima gaji di atas 15 juta rupiah perbulan sebanyak 2 orang $(2,0 \%)$. Berdasarkan hasil survei menunjukkan bahwa mayoritas gaji karyawan kantor pusat PT. Jasa Swadaya Utama di bawah 5 juta rupiah $55,1 \%$. Hal ini menunjukkan dengan mayoritas gaji rendah kurang menunjang loyalitas dan produktivitas karyawan itu sendiri. 
Model Pengukuran Outer Model

\section{a. Uji Validitas}

Hasil Uji Validitas

\begin{tabular}{|c|c|c|c|c|c|}
\hline & $\begin{array}{c}\text { Original } \\
\text { Sample }\end{array}$ & $\begin{array}{c}\text { Sample } \\
\text { Mean }\end{array}$ & $\begin{array}{c}\text { Standard } \\
\text { Deviation }\end{array}$ & $\begin{array}{c}\mathrm{T} \\
\text { Statistik }\end{array}$ & $\begin{array}{c}\mathrm{P} \\
\text { Values }\end{array}$ \\
\hline $\mathrm{X} 1.1$ & 0,764 & 0,759 & 0,059 & 12,936 & 0.000 \\
\hline $\mathrm{X} 1.2$ & 0,829 & 0,828 & 0,031 & 26,827 & 0.000 \\
\hline $\mathrm{X} 1.3$ & 0,853 & 0,852 & 0,030 & 28,141 & 0.000 \\
\hline $\mathrm{X} 1.4$ & $-0,778$ & $-0,780$ & 0,050 & 15,621 & 0.000 \\
\hline $\mathrm{X} 1.5$ & 0,756 & 0,756 & 0,046 & 16,270 & 0.000 \\
\hline $\mathrm{X} 1.6$ & 0,793 & 0,795 & 0,040 & 19,681 & 0.000 \\
\hline $\mathrm{X} 1.7$ & 0,735 & 0,736 & 0,059 & 12,428 & 0.000 \\
\hline $\mathrm{X} 2.1$ & 0,751 & 0,750 & 0,058 & 13,048 & 0.000 \\
\hline $\mathrm{X} 2.2$ & 0,848 & 0,844 & 0,038 & 22,120 & 0.000 \\
\hline $\mathrm{X} 2.3$ & 0,469 & 0,467 & 0,080 & 5,853 & 0.000 \\
\hline $\mathrm{X} 2.4$ & 0,733 & 0,732 & 0,063 & 11,636 & 0.000 \\
\hline $\mathrm{X} 2.5$ & 0,867 & 0,865 & 0,037 & 23,618 & 0.000 \\
\hline $\mathrm{X} 2.6$ & 0,921 & 0,919 & 0,028 & 33,209 & 0.000 \\
\hline $\mathrm{X} 2.7$ & 0,771 & 0,766 & 0,053 & 14,490 & 0.000 \\
\hline $\mathrm{X} 2.8$ & 0,829 & 0,828 & 0,042 & 19,672 & 0.000 \\
\hline $\mathrm{X} 2.9$ & 0,819 & 0,818 & 0,047 & 17,614 & 0.000 \\
\hline $\mathrm{X} 2.10$ & 0,677 & 0,673 & 0,078 & 8,723 & 0.000 \\
\hline $\mathrm{Y} 1$ & 0,800 & 0,797 & 0,042 & 18,928 & 0.000 \\
\hline $\mathrm{Y} 2$ & 0,870 & 0,867 & 0,037 & 23,598 & 0.000 \\
\hline $\mathrm{Y} 3$ & 0,694 & 0,697 & 0,061 & 11,468 & 0.000 \\
\hline $\mathrm{Y} 4$ & 0,629 & 0,625 & 0,065 & 9,694 & 0.000 \\
\hline $\mathrm{Y} 5$ & 0,830 & 0,827 & 0,040 & 20,751 & 0.000 \\
\hline $\mathrm{Y} 6$ & 0,885 & 0,884 & 0,031 & 28,699 & 0.000 \\
\hline $\mathrm{Y} 7$ & 0,463 & 0,454 & 0,091 & 5,100 & 0.000 \\
\hline $\mathrm{Y} 8$ & 0,844 & 0,841 & 0,046 & 18,451 & 0.000 \\
\hline $\mathrm{Y} 9$ & 0,725 & 0,723 & 0,060 & 12,045 & 0.000 \\
\hline $\mathrm{Y} 10$ & 0,819 & 0,815 & 0,040 & 20,552 & 0.000 \\
\hline $\mathrm{Y} 11$ & 0,458 & 0,460 & 0,096 & 4,772 & 0.000 \\
\hline $\mathrm{Y} 12$ & 0,707 & 0,704 & 0,058 & 12,090 & 0.000 \\
\hline $\mathrm{Y} 13$ & 0,584 & 0,586 & 0,071 & 8,274 & 0.000 \\
\hline S & & \\
\hline
\end{tabular}

Sumber : Data diolah SEM - SmartPLS 3

Nilai outer loading merupakan korelasi antara indikator dengan konstruknya. Semakin tinggi korelasinya, semakin tinggi pula tingkat validitasnya dan juga 
menunjukkan tingkat validitas yang lebih baik.

\section{b. Uji Reliabilitas}

Convergent validity adalah reliability konstruk dengan memperhatikan nilai Composite Reliability (CR), Cronbach's Alpha (CA), dan Average Variance Extracted (AVE). Hasil Uji reliability dapat dilihat pada tabel sebagai berikut :

\section{Hasil Uji Reliability}

\begin{tabular}{|l|c|c|c|c|}
\hline & $\begin{array}{l}\text { Cronbach`s } \\
\text { Alpha }\end{array}$ & Rho_A & $\begin{array}{l}\text { Composite } \\
\text { Reliability }\end{array}$ & $\begin{array}{l}\text { Avarege } \\
\text { Variance } \\
\text { (AVE) }\end{array}$ \\
\hline Kompetensi & 0,911 & 0,913 & 0,931 & 0,692 \\
\hline $\begin{array}{l}\text { Kepemimpinan } \\
\text { Transformasional }\end{array}$ & 0,941 & 0,945 & 0,950 & 0,681 \\
\hline Produktivitas Kerja & 0,938 & 0,945 & 0,947 & 0,621 \\
\hline
\end{tabular}

Sumber : Data diolah SEM - SmartPLS 3

Hasil pengolahan uji reliability pada variable kompetensi, kepemimpinan transpormasional, dan produktivitas kerja didapatkan nilai Composite Reliability (CR) untuk semua konstruk lebih besar dari 0,7 yang menunjukkan bahwa semua konstruk pada model destimasi memenuhi kriteria discriminant validity. Dengan demikian hasil pengujian Composite Reliability (CR) menunjukkan reliabel. Sedangkan nilai Cronbach's Alpha (CA) untuk semua konstruk adalah lebih besar 0,7 . Dengan demikian hasil pengujian Cronbach's Alpha (CA) menunjukkan reliable.

Menurut Hair et, al (1998), direkomendasikan nilai Average Variance Extracted (AVE) untuk semua konstruk harus lebih besar dari 0,5. Berdasarkan tabel di atas menunjukkan bahwa nilai akar dari AVE untuk setiap konstruk adalah lebih besar dari 0,5 atau lebih. Dengan demikian hasil pengujian Average Variance Extracted (AVE) semua reliable. Berdasarkan hasil seluruh uji instrument dari uji validitas dan reliabilitas dinyatakan bahwa semua butir pernyataan memenuhi persyaratan untuk dipakai dalam instrument penelitian.

\section{Pengujian Model Struktural (Inner Model)}

\section{a. Pengujian Hipotesis}

Hasil pengolahan data variable kompetensi, kepemimpinan transformasional, dan produktivitas kerja dapat dilihat pada tabel di bawah ini : 


\section{Hasil Uji Hipotesis}

\begin{tabular}{|c|c|c|c|c|c|c|}
\hline & $\begin{array}{l}\text { Original } \\
\text { Sample }\end{array}$ & $\begin{array}{c}\text { Sample } \\
\text { Mean }\end{array}$ & $\begin{array}{l}\text { Standard } \\
\text { Deviation }\end{array}$ & $\begin{array}{c}\mathrm{T} \\
\text { Statistics }\end{array}$ & $\begin{array}{c}\mathrm{P} \\
\text { Values }\end{array}$ & Ket \\
\hline $\mathrm{K} \rightarrow \mathrm{PK}$ & 0,738 & 0,744 & 0,085 & 8,681 & 0,000 & $\begin{array}{c}\text { Highly } \\
\text { Significant }\end{array}$ \\
\hline $\mathrm{K}>\mathrm{KT}$ & 0,922 & 0,921 & 0,019 & 48,746 & 0,000 & $\begin{array}{c}\text { Highly } \\
\text { Significant }\end{array}$ \\
\hline $\mathrm{KT} \rightarrow \mathrm{PK}$ & 0,216 & 0,210 & 0,089 & 2,435 & 0,015 & Significant \\
\hline
\end{tabular}

Sumber : Data diolah SEM - SmartPLS 3, 2020

1) Pembuktian Hipotesis 1 : Kompetensi berpengaruh positif dan signifikan terhadap Produktivitas Kerja. Tabel di atas menunjukkan hasil Original Sample $=0,738, \mathrm{~T}$ Statistics $=8,681, \mathrm{P}$ Values $=$ $0,000 \quad(<0,05)$. Hal ini menunjukkan bahwa pengaruh antara kompetensi terhadap produktivitas kerja adalah signifikan.

2) Pembuktian Hipotesis 2 : Kompetensi berpengaruh positif dan signifikan terhadap kepemimpinan transformasional. Tabel 4.9 menunjukkan hasil Original Sample $=0,922$, T Statistics $=48,746, \mathrm{P}$ Values $=0,000$. Hal ini menunjukkan bahwa pengaruh antara kompetensi terhadap kepemimpinan transpormasional adalah signifikan.

3) Pembuktian Hipotesis 3 : Kepemimpinan Transformasional berpengaruh positif dan signifikan produktivitas kerja. Tabel 4.9 menunjukkan hasil Original Sample $=0,216$, $T$ Statistics $=2,435, \mathrm{P}$ Values = 0,015. Hal ini menunjukkan bahwa pengaruh antara kepemimpinan transformasional terhadap produktivitas kerja adalah signifikan.

4) Pembuktian Hipotesis 4 : Kompetensi dan Kepemimpinan Transformasional berpengaruh positif dan signifikan terhadap Produktivitas Kerja. Tabel 4.10 menunjukkan hasil RSquare Adjusted produktivitas kerja 0,868. Hal ini menunjukkan bahwa pengaruh antara kompetensi dan kepemimpinan transformasional terhadap produktivitas kerja adalah signifikan.

\section{b. Koefisien Determinasi}


Berikut disajikan hasil dari koefisien determinasi,

sebagai

berikut

R Square

\begin{tabular}{|c|c|c|}
\hline & R Square & $\begin{array}{c}\text { R Square } \\
\text { Adjusted }\end{array}$ \\
\hline $\begin{array}{c}\text { Kepemimpinan } \\
\text { Transformasional }\end{array}$ & 0,850 & 0,848 \\
\hline Produktivitas kerja & 0,884 & 0,868 \\
\hline
\end{tabular}

Sumber : Data diolah SEM - SmartPLS 3

Berdasarkan tabel di atas dapat diketahui bahwa nilai $R$ Square Adjusted produktivitas kerja $=0,868$. Hal ini menunjukkan bahwa pengaruh kompetensi dan kepemimpinan transformasional terhadap produktivitas kerja sebesar $86,8 \%$ sedangkan sisanya $13,2 \%$ dipengaruhi faktor lain.

\section{a) Pengaruh Kompetensi terhadap Produktivitas Kerja.}

Menjawab rumusan masalah yang berkaitan dengan hipotesis satu $(\mathrm{H} 1)$ dapat diamati dari hasil analisis software SEM SmartPLS 3 pada tabel. Berdasarkan tabel tersebut dapat diketahui bahwa variabel kompetensi berpengaruh positif signifikan terhadap produktivitas kerja yang ditunjukkan dengan nilai original sampel 0,738 dan $T$ Statistics $8,681>1,96$ T-Table dan $\mathrm{P}$ Values $=0,000(<0,05)$. Hasil hipotesis menunjukkan bahwa kompetensi berpengaruh positif dan signifikan terhadap produktivitas kerja terbukti kebenarannya atau $\mathrm{H} 1$ diterima. Kompetensi merupakan cerminan 3 (tiga) indikator yaitu
Pengetahuan, keterampilan, dan sikap.

Nilai outer loading pengetahuan lebih dari 0,5 yang menunjukkan bahwa dalam melaksanakan pekerjaan harus memahami teori yang berkaitan dengan pekerjaan, tingkat pendidikan yang sesuai dengan bidang pekerjaan, dan mengerti dengan apa yang menjadi tanggung jawab dalam pekerjaannya. Nilai outer loading keterampilan lebih dari 0,5 yang menunjukkan bahwa setiap karyawan harus memiliki keterampilan dengan kreativitas dan inovasi yang baik dan dapat memecahkan permasalahan yang ada dalam pekerjaannya. Nilai outer loading sikap lebih dari 0,5 yang menunjukkan bahwa dalam bekerja setiap karyawan harus mematuhi norma-norma social, bisa bekerja sama memenuhi aturan dan ketentuan yang berlaku, serta disiplin waktu dengan hadir tepat waktu. Orang yang memiliki pengetahuan wawasan dalam pekerjaan, memiliki keterampilan dengan jiwa kreatif dan inovatif, serta memiliki sikap yang baik di dalam 
perusahaan

maupun

lingkungannya merupakan salah satu karyawan yang mempunyai kompetensi yang sangat diharapkan oleh manajemen perusahaan manapun.

Berdasarkan dari hasil analisa data di atas hasil hipotesa dari kompetensi terhadap produktivitas kerja adalah positif dan signifikan. Hal ini berarti bahwa dengan adanya kompetensi dengan menerapkan filsafat kaizen untuk perbaikan terus menerus ke arah yang lebih baik. Perbaikan secara terus menerus akan dapat meningkatkan produktivitas kerja karyawan seperti melahirkan inovasi dan memperkecil resiko, sehingga target atas visi dan misi perusahaan akan tercapai, begitu pula sebaliknya.

Hasil penelitian ini sejalan dengan penelitian sebelumnya yang dilakukan oleh Falentina (2018) dan Tumiwa (2017) dimana kompetensi berpengaruh secara signifikan terhadap produktivitas kerja karyawan.

\section{b) Pengaruh Kompetensi terhadap Kepemimpinan Transformasional}

Menjawab rumusan masalah yang berkaitan dengan hipotesis dua $(\mathrm{H} 2)$ dapat diamati dari hasil analisis software SEM SmartPLS 3 pada tabel. Berdasarkan tabel tersebut dapat diketahui bahwa variable Kompetensi berpengaruh positif dan signifikan terhadap Kepemimpinan Transformasional yang ditunjukkan dengan nilai original sample 0,922 dan $T$
Statistics 48,746 > 1,96 T-Table dan $P$ Values $=0,000(<0,05)$. Hasil hipotesis menunjukkan bahwa Kompetensi berpengaruh positif dan signifikan terhadap Kepemimpinan Transformasional terbukti kebenarannya atau $\mathrm{H} 2$ diterima. Kompetensi merupakan cerminan 3 (tiga) indikator yaitu Pengetahuan, keterampilan, dan sikap.

Nilai outer loading pengetahuan lebih dari 0,5 yang menunjukkan bahwa dalam melaksanakan pekerjaan harus memahami teori yang berkaitan dengan pekerjaan, tingkat pendidikan yang sesuai dengan bidang pekerjaan, dan mengerti dengan apa yang menjadi tanggung jawab dalam pekerjaannya. Nilai outer loading keterampilan lebih dari 0,5 yang menunjukkan bahwa setiap karyawan harus memiliki keterampilan dengan kreativitas dan inovasi yang baik dan dapat memecahkan permasalahan yang ada dalam pekerjaannya. Nilai outer loading sikap lebih dari 0,5 yang menunjukkan bahwa dalam bekerja setiap karyawan harus mematuhi norma-norma social, bisa bekerja sama memenuhi aturan dan ketentuan yang berlaku, serta disiplin waktu dengan hadir tepat waktu. Orang yang memiliki pengetahuan wawasan dalam pekerjaan, memiliki keterampilan dengan jiwa kreatif dan inovatif, serta memiliki sikap yang baik di dalam perusahaan maupun lingkungannya merupakan salah satu karyawan yang mempunyai 
kompetensi yang sangat diharapkan oleh pimpinan perusahaan manapun.

Berdasarkan dari hasil analisa data di atas hasil hipotesa dari kompetensi terhadap kepemimpinan transformasional adalah positif dan signifikan. Hal ini berarti bahwa dengan adanya kompetensi yang sesuai dari setiap karyawan dalam perusahaan, maka akan mempermudah dalam penyesuaian dan pelaksanaan tugasnya, sehingga target atas visi dan misi perusahaan akan tercapai, begitu pula sebaliknya.

Hasil penelitian ini sejalan dengan penelitian sebelumnya yang dilakukan oleh Supartini, Tini, 2017. Dimana kompetensi berpengaruh positif dan signifikan terhadap kepemimpinan transformasional.

\section{c) Pengaruh Kepemimpinan Transformasional terhadap Produktivitas Kerja}

Menjawab rumusan masalah yang berkaitan dengan hipotesis tiga $(\mathrm{H} 3)$ dapat diamati dari hasil analisis software SEM SmartPLS 3 pada tabel 4.9. Berdasarkan tabel tersebut dapat diketahui bahwa variable kepemimpinan transformasional berpengaruh positif dan signifikan terhadap produktivitas kerja yang ditunjukkan dengan nilai original sample 0,216 dan $T$ Statistics 2,435 > 1,96 T-Table dan P Values $=0,015(<0,05)$. Hasil hipotesis menunjukkan bahwa kepemimpinan transformasional berpengaruh positif dan signifikan terhadap produktivitas kerja terbukti kebenarannya atau $\mathrm{H} 3$ diterima. Kepemimpinan transformasional merupakan cerminan 4 (empat) indikator yaitu motivasi inspirasional, pengaruh ideal, stimulasi intelektual, dan perhatian individu.

Nilai outer loading motivasi inspirasional lebih dari 0,5 yang menunjukkan bahwa seorang pemimpin perusahaan harus bisa memberikan motivasi secara terus menerus dan dapat menumbuhkan dan membangkitkan antusiasme kepada karyawannya dengan baik. Nilai outer loading pengaruh ideal lebih dari 0,5 yang menunjukkan bahwa sebagai seorang pemimpin harus bisa menjadi panutan bagi karyawan dan mempunyai pengetahuan dan wawasan luas sehingga dapat mengajarkan dan memberikan petunjuk serta solusi dalam menyelesaikan permasalahan dalam pekerjaan. Nilai outer loading stimulasi intelektual lebih dari 0,5 yang menunjukkan bahwa seorang pemimpin dalam suatu organisasi perusahaan harus mampu mendorong dan mendukung karyawannya untuk melakukan kreativitas dan inovatif dalam melaksanakan pekerjaannya dan mampu menyelesaikan permasalahan dari berbagai sudut pandang. Nilai outer loading perhatian individu lebih besar dari 0,5 yang menunjukkan bahwa dalam rangka meningkatkan kemampuan karyawannya pemimpin harus memberikan pengetahuan tambahan dengan pelatihan yang berhubungan 
dengan pekerjaan baik secara internal maupun eksternal, mengetahui dan memahami keadaan karyawannya, bersedia mendengarkan kesulitan dan keluhan yang dialami karyawannya, dan dapat menempatkan posisi karyawannya sesuai dengan pendidikan dan kemampuan masing-masing.

Hasil penelitian ini sejalan dengan penelitian sebelumnya yang dilakukan oleh Miraji Urip (2017) dimana hasil penelitiannya menunjukkan terdapat keterkaitan dengan kategori sedang, positif dan signifikan antara gaya kepemimpinan transpormasional terhadap produktivitas kerja. Hal ini artinya semakin tinggi gaya kepemimpinan transpormasional yang ditunjukkan oleh pimpinan dan semakin tinggi motivasi Kerja karyawan akan meningkatkan produktivitas kerja karyawan

\section{d) Pengaruh kompetensi dan kepemimpinan transformasional terhadap produktivitas kerja}

Menjawab rumusan masalah yang berkaitan dengan hipotesis empat $(\mathrm{H} 4)$ dapat diamati dari hasil analisis software SEM SmartPLS 3 pada tabel. Berdasarkan tabel tersebut dapat diketahui bahwa variable Kompetensi dan Kepemimpinan Transformasional berpengaruh positif dan signifikan terhadap produktivitas kerja yang ditunjukkan dengan nilai $R$ Square Adjusted Produktivitas Kerja 0,868. $\mathrm{Hal}$ ini menunjukkan bahwa pengaruh kompetensi dan kepemimpinan transformasional terhadap produktivitas kerja sebesar 86,8\%. Hasil hipotesis menyatakan bahwa kompetensi dan kepemimpinan transformasional berpengaruh positif dan signifikan terhadap produktivitas kerja terbukti kebenarannya atau $\mathrm{H} 4$ dapat diterima.

Penelitian ini menunjukkan adanya hubungan yang positif antara kompetensi dan kepemimpinan transformasional dengan produktivitas kerja, dengan kata lain dapat pula dikatakan bahwa semakin tinggi atau semakin baik kompetensi dan kepemimpinan transformasional yang ada pada kantor pusat PT Jasa Swadaya Utama - Jakarta Timur, maka secara otomatis akan semakin meningkatkan atau mempengaruhi produktivitas kerja karyawan dalam melaksanakan tugas dan tanggung jawabnya di tempat kerja. Jika kompetensi dan kepemimpinan transformasional mendapat perhatian dari manajemen dan dengan didukung oleh produktivitas kerja karyawan yang baik, maka tujuan dari perusahaan PT Jasa Swadaya Utama akan tercapai atau terwujud sesuai dengan visi dan misinya.

\section{KESIMPULAN}

1. Hasil Analisis data menyimpulkan bahwa Kompetensi berpengaruh positif dan signifikan terhadap Produktivitas Kerja sebesar 0,738 dimana $\mathrm{P}$ Values $=$ $0,000 \quad(<0,05)$. Hal ini menunjukkan bahwa pengaruh antara kompetensi terhadap 
produktivitas kerja adalah signifikan. Artinya kompetensi berpengaruh dan signifikan terhadap produktivitas kerja. Semakin tinggi kompetensi maka produktivitas kerja karyawan di PT Jasa Swadaya Utama pun akan meningkat. Hal ini berarti bahwa dengan adanya kompetensi akan membawa perbaikan terus menerus ke arah yang lebih baik. Perbaikan secara terus menerus akan dapat meningkatkan produktivitas kerja karyawan seperti melahirkan inovasi dan memperkecil resiko, sehingga target atas visi dan misi perusahaan akan tercapai, begitu pula sebaliknya.

2. Hasil Analisis data menunjukkan bahwa Kompetensi berpengaruh positif dan signifikan terhadap Kepemimpinan

Transformasional sebesar 0,922 dimana $P$ Values $=$ $0,000 \quad(<0,05)$. Hal ini menunjukkan bahwa pengaruh antara kompetensi terhadap Kepemimpinan

Transformasional adalah signifikan. Dalam rangka meningkatkan kemampuan karyawannya pemimpin harus memberikan pengetahuan tambahan dengan pelatihan yang berhubungan dengan pekerjaan baik secara internal maupun eksternal, mengetahui dan memahami keadaan karyawannya, bersedia mendengarkan kesulitan dan keluhan yang dialami karyawannya, dan dapat menempatkan posisi karyawannya sesuai dengan pendidikan dan kemampuan masing-masing.

3. Hasil analisis data menunjukkan

Kepemimpinan

Transpormasional

berpengaruh positif dan signifikan terhadap produktivitas kerja. Sebesar 0,216 , dimana nilai $P$ Values adalah $0,015(<0,05)$ Hal ini menunjukkan bahwa pengaruh antara kepemimpinan transformasional terhadap produktivitas kerja adalah signifikan. Artinya semakin tinggi kepemimpinan transpormasional yang ditunjukkan oleh pimpinan dilihat dari indikator motivasi inspirasional, pengaruh ideal, stimulasi intelektual, dan perhatian individu maka produktivitas kerja karyawanpun akan meningkat.

4. Hasil analisis data menunjukkan bahwa Kompetensi dan Kepemimpinan

Transpormasional berpengaruh positif dan signifikan terhadap produktivitas kerja yang ditunjukkan dengan nilai $R$ Square Adjusted Produktivitas Kerja 0,868. Hal ini menunjukkan bahwa pengaruh kompetensi dan kepemimpinan transpormasional terhadap produktivitas kerja sebesar 86,8\%. Hasil hipotesis menyatakan bahwa kompetensi dan kepemimpinan transpormasional berpengaruh 
positif dan signifikan terhadap produktivitas kerja

\section{DAFTAR PUSTAKA}

1.Davis, Keith and Newstrom, W.John, 1989. Human Behavior at Work: Organizational Behavior. New York: McGraw Hill International

2. Erkutlu, Hakan, 2008. The Impact of Transformational Leadership on Organizational and Leadership Effectiveness The Turkish Case. Journal of Management Development, 27(7), pp: 708-726

3. Hair et, al 1998. Multivariate Data Analysis, Englewood Cliffs, NJ: Prentice Hall.

4. Mar'ih, Suci Rahayu, 2016. Mudah Menyusun Kualifikasi dan Performa Karyawan, Raih Asa Sukses, Jakarta.

5. Marshall, Patricia, 2003. Mengapa Beberapa Orang Lebih Sukses Dari Yang
Lainnya. Manusia dan Kompetensi Panduan Praktis Untuk Keunggulan Bersaing. Editor Boulter, Murray Dalziel, dan Jackie Hill. Alih Bahasa. Bern. Hidayat. Penerbit PT Bhuana Ilmu Populer.

6. Marwansyah, 2012. Manajemen Sumber Daya Manusia, Alfabeta, Bandung.

7. Mulyadi, H, 2010. Pengaruh Motivasi dan Kompetensi Kerja Terhadap Produktivitas Kerja Karyawan Pada PT. Galamedia Bandung Perkasa. Jurnal Manajerial Vol.9 No. 17, Universitas Pendidikan Indonesia.

8. Robbins, S.P, 2003. Organizational Behavior Upper Saddle River : Pearson Education.

9. Serdamayanti, 2009. Sumber Daya Manusia dan Produktivitas Kerja. Bandung : CV. Mandar Maju.

10. Spencer, Peter M., \& Signe M. Spencer, 1993. Competence at Work " Models For Superior Performance". New York: Jhon Wiley \& Sons Inc. 